\title{
THE RIVER QOUEIQ AND ITS IMPORTANCE FOR EBLA (SYRIA) AT THE TIME OF THE ARCHIVES (XXIV CENT. BC): SOME OBSERVATION
}

\author{
Maria Giovanna Biga-Ahmad Karbotly \\ (Sapienza Università di Roma)
}

\begin{abstract}
The river Qoueiq (which flows close to the big city of Aleppo) has been important in the history of Syria already in the third millennium $B C$.

Along its valley there are many tells, studied mostly in surveys from the 1970s; some of them are certainly to be dated to the third millennium $B C$ and their name could be present in the Ebla texts. They are not yet identified with ancient cities. Tell Tuqan, on the lake Matkh in which the river disappears, or Tell Hader in the river valley, can likely be identified with NIrar of the Ebla texts.
\end{abstract}

\section{KEYWORDS:}

River Qoueiq, surveys, lake Matkh, Tell Tuqan, Tell Hader, kingdom of NIrar.

\section{RIASSUNTO}

Il fiume Qoueiq (che scorre presso la città di Aleppo) è stato importante anche nella storia della Siria del III millennio a.C.

Nella sua valle ci sono molti tell, studiati per lo più in surveys a partire dagli anni '70. Alcuni di loro sono certamente da datare al III millennio a.C., ma non è possibile identificarli con toponimi menzionati nei testi di Ebla. Tell Tuqan, sul lago Matkh nel quale il fiume si getta, o Tell Hader possono essere identificati tentativamente con la città di NIrar dei testi di Ebla.

\section{PAROLE CHIAVE}

Fiume Qoueiq, surveys, lago Matkh, Tell Tuqan, Tell Hader, regno di NIrar.

\section{Introduction}

The capital city of Ebla (modern Tell Mardikh, Syria, around $60 \mathrm{kms}$ South West of Aleppo) was in internal Syria and not on a river or on a lake. For this reason it is of primary importance to understand how water was obtained and how it was managed.

The written sources at our disposal, i.e. Ebla's archives (dating to the 24th cent. BC and illuminating around 40 years of the city's life) are mostly administrative documents relating to deliveries of goods from the Eblaite storerooms and do not give many information on water management. Nor do they mention rivers. The rivers Qoueiq, Orontes, Balikh, Euphrates are not cited in the Ebla administrative texts, even if several cities referred to have been supposed to be on one of these rivers.

In the almost contemporary texts of Mari and Tell Beydar no mention of rivers is present.

The Eblaite scribes used the Sumerian logogram "a" to indicate water.

In ARET XVI $27 \S 33$ there is possibly a reference to a gate $\left(a-u_{x}\right)$ to stop water (of a river?) but the passage is difficult.

A word indicating canal is very rarely attested in the Ebla texts ${ }^{1}$.

\footnotetext{
${ }^{1}$ For an example s. ARET XVI, $5 \S 6$ obv. IV 10 and commentary at p. 51 where the Sumerogram for canal used by the Eblaite scribe is e-še compared by Fronzaroli with e-še-á, which in texts of Lagaš is used to indicate an irrigation canal. For the lexikon of water in the Ebla texts s. Bonechi 1999.
}

Isimu 23 (2020): 41-52

https://doi.org/10.15366/isimu2020.23.002

ISSN: 1575-3492 
In the Ebla texts, there are several quotations of wells; the news of the excavation of a new well (pú) was immediately brought to the court. It was important for Eblaite messangers, ambassadors, and merchants traveling in the country etc. to know where wells were and if water was available. Even if several places where wells had been excavated cannot be located precisely, it is quite probable that almost all refer to villages of the territory controlled by Ebla, i.e. Ebla chora².

There is no word for "lake" even if some lakes were not too far from Ebla and lake Matkh on which there is Tell Tuqan is around $15 \mathrm{kms}$ from Ebla and the salt lake Jabboul is around $70 \mathrm{~km}$ away. Although they were not far away from Ebla, both were thus probably not mentioned in the texts.

Although in the ancient Near East, the same word could designate a lake or a sea, no mention of a sea has been attested so far in the Ebla textual evidence.

Apart from the rivers Balikh and Euphrates cited in literary texts that were probably imported and not written in Ebla itself ${ }^{3}$, no rivers are referred to in the Ebla texts.

In addition, the name of river Qoueiq does not appear to my knowledge in the Ebla texts, but it is very close to Ebla and must have been an important source of water for the city, possibly, as we will see, thanks also to some canals.

The river Qoueiq (Nahar el-Quwayq/Quweiq/Qoueiq) is $129 \mathrm{~km}$ long. Its source is in the hills of Antep in the south of modern Turkey; after river Akpinar as a tributary, it reaches Aleppo and then forms Lake Matkh in which it disappears. The region of the river Qoueiq and the region of the lake Matkh and its tributaries north of Aleppo is rich of water with a relatively high water table.

\section{Surveys in the valley of the river Qoueiq and excavations of sites of the region between Aleppo and Ebla.}

The valley of the river Qoueiq has been the object of surveys since the 1970s. Apart from the city of Aleppo, the tells along the river have not been excavated.

M. Liverani in 1964 carried out a survey of the pre-classical tell around Tell Mardikh, proposing the identification of Tell Mardikh with ancient Ebla. (Liverani 1965). A. de Maigret, with other members of the Italian archaeological mission in Syria at Tell Mardikh/Ebla, visited the sites of the river Qoueiq area and of Al-Matakh/Matkh marshes south of Aleppo during 1971, 1972 and 1974 and the survey is still an important source of information ${ }^{4}$, fournishing a comprehensive documentation of that area.

J. Matthers carried out surveys in the river Qoueiq region between 1977 and 1979, following the river from the Turkish border until its disappearance into lake Matkh, documenting 88 sites. publishing the results in $1981^{5}$.

A project, supervised by K. Kohlmeyer and J. Klinger, has been carried out by a group of scholars including R. Del Fabbro and studied the region around Aleppo ${ }^{6}$ and its river Qoueiq with a radius of about 30-35 km using historical-philological and archaeological sources, publishing several articles ${ }^{7}$.

\footnotetext{
${ }^{2}$ Biga 2013.

${ }^{3}$ ARET V 5, VII 7; ARET V 3 §4.

${ }^{4}$ de Maigret 1978.

${ }^{5}$ Matthers 1981.

${ }^{6}$ Aleppo is the only site of the valley that can be identified with certainty. Certainly its position close to the river was a strategic choice which favoured the development of the city. It soon became the most important centre of northern Syria, probably immediately after the fall of Ebla around 2300-2250, and still is important.

${ }^{7}$ Knitter et al. 2014, with previous bibliography; Del Fabbro 2012.
} 
Their study included also the area "to the east, the Al-Matah/Madkh region, i.e. the marshy area where the Nahr al-Quwayq disappears"8. R. Dal Fabbro studied also all textual material, especially of historical-geographical interest, gathered and analysed in order to identify-whenever possible- the ancient names of the archaeological sites and their change in toponimy during different ages.

She concluded that "during the second half of the third millennium BC (i.e. at the time of the Ebla archives) and the first half of the second millennium BC, the route Aleppo-Ebla had to be particularly important. These two sites are about $55 \mathrm{~km}$ away, that is to say, a two -day journey"9.

She also studied the northern connection between the Nahr al-Qoueiq and the Nahr edhDhahab, two rivers that flow almost parallels. The same conclusions are reached in a recent article "Due to the geology and the corresponding relief character there are no navigable streams connecting the west and the east. Qoueiq is the only perennial stream in the area around Aleppo"10.

An ERC project, Ebla chora, financed by the European Union in 2010, sponsored the Italian archaeological mission at Tell Mardikh/Ebla, which studied a region of 3,500 $\mathrm{km}$ around Ebla, including also the valley of river Qoueiq, from the archaeological and textual sources ${ }^{11}$. It was stopped by the terrible Syrian war which began on 2011 and is still continuing. The project did a preliminary inventory of 85 sites dating from the early Bronze Age to the classical period, putting together all the data from the previous surveys including that of De Maigret at the beginning of the 1970s and that of Matthers at the end of the 1970s.

Among the 85 sites, 22 sites have been recorded in the area of the river Qoueiq. Other regions very close to the Qoueiq valley have been investigated, such as the region of Jazr with Tell Afis. Among the tells identified in this area, only Tell Mastuma and Tell Afis ${ }^{12}$ have been excavated.

All the surveys highlight that it remains difficult to ascertain the dimension of sites. The sites in the river valley are close to each other. For example Tell Allush is located $7 \mathrm{~km}$ to the north-east of Tell Tuqan, the biggest tell on the western side of the lake. Tell Berne, another relatively big tell, (8ha?) is ca $18 \mathrm{~km}$ further north along the river Qoueiq. Vacca concludes that "all these sites are situated in strategic positions controlling access to the Matkh plain, which constitutes a crossroad from Ebla toward the Jabbul Plain and the Euphrates to the east, and Aleppo to the north"13.

In the EB IVA (2550-2300 BC), i.e. during the time of the Ebla archives there was a marked increase in the number of settlements to 21 .

On Lake Matkh there is a bit tell, Tell Tuqan, excavated from 2006 by an Italian archaeological mission directed by F. Baffi who studied also the region around the lake. The

\footnotetext{
${ }^{8}$ Del Fabbro 2012: 205.

${ }^{9}$ All over the world, from the beginning of the history to the present, rivers (and canals) had been used as a communications route and to carry heavy materials such as stones and timber more easily.

${ }^{10}$ Knitter et al. 2014.

${ }^{11}$ Vacca 2019.

${ }^{12}$ The archaeological evidence from Tell Afis "suggests a period of decreasing occupation of the tell beginning in EBI and ending in EBIVB, probaby following the rise and collapse of the Eblaite hegemony" (Vacca 2019: 874). Thanks to the discovery of fragmentary stone vases imported from Egypt and comparable with specimens retrieved in Palace G at Ebla, Matthiae 2014: 41 proposed that Tell Afis has been a secondary royal residence of the king of Ebla during the period of the archives (EBIVA).

${ }^{13}$ For a similar conclusion see Steinkeller 2020 (in print).
} 
site was settled from EB III to the Islamic period ${ }^{14}$. On the river Qoueiq another important contemporary tell is Tell Hader.

Tell Tuqan and Tell Hader still seem relatively small during EB IVA, increasing in size and importance only from EB IVB, following the demise of the regional power of Ebla. Tell Tuqan and Tell Hader are 26 and 16 ha respectively in EB IVB, after the fall of Ebla.

A very interesting and important fact is that in another area close to the river Qoueiq, the steppe area at the piedmont of Jebel el-Hass occupied since at least the mid-3rd millennium BC., 4 sites can be dated to EB IVA. As Vacca observed "two of these sites, Tell Munbatah and Tell Sabka, are probably newly founded settlements (with circular urban planning) located in a strategic position within the corridor of Khanaser, which gives access to the Jabbul Lake and, further east, to the Euphrates river".

\section{Tell Tuqan or Tell Hader = NIrar of the Ebla texts?}

Thanks to the data of the written sources, i.e. the texts of Ebla, an identification of Tell Tuqan with the ancient capital city of NIrar ( written NI-ra/la-ar ${ }^{k i}$ ) has been proposed by Biga ${ }^{15}$.

There are no itineraries referred to by the Eblaite scribes registering the textiles deliveries from Ebla storerooms to different people in Ebla or outside Ebla for different purposes. Therefore, Biga, in several studies proposed locations of some sites according to the product coming to Ebla. Examples are ivory and linen textiles coming to Ebla from Dugurasu, and linen also from DUlu/Gublu because the city was a stop on the commercial road between Egypt and Ebla etc... ${ }^{16}$. It is more difficult to identify a city from the gift of wine because vineyards were cultivated in a large area from the Mediterranean coast to the region of today's Idlib. The same is true for oil.

Products coming from the court of NIrar to the Eblaite court include milk and cream, fresh products that cannot withstand a long trip. Therefore ${ }^{17}$, it is possible to propose that the kingdom of NIrar was very close to Ebla.

Another important point in favour of locating NIrar close to the waters of river Qoueiq or lake Matkh comes from the two texts of the royal rituals published by Pettinato and in ARET XI ${ }^{18}$. The purpose of the ritual is still controversial among scholars ${ }^{19}$ but it was performed at least twice, once at the time of the penultimate king Irkab-damu, and then at the time of the last king Išar-damu. Both texts narrate the solemn procession with two chariots with the god KUra and Barama and the king and the queen, accompanied by some cultic functionaries and probably between two lines of crowd. Traveling very slowly, it leaves Ebla to reach the city of Binaš $^{20}$ where the ceremonies in honor of some deified royal ancestors will take place. The first stop of the trip is "at the waters of Masad, those of

\footnotetext{
${ }^{14}$ Baffi 2011; Baffi-Peyronel 2013; Mantellini 2013.

${ }^{15}$ Biga 2008: 306-307; 2014: 92 n.2.

${ }^{16}$ Biga-Roccati 2010; Biga 2016; Biga-Steinkeller, in print.

${ }^{17}$ Fresh products such as fish, cheese, fruit were exchanged by Renaissance courts too. In some letters of Lucrezia Borgia published in a recent volume (Lettere: 1494-1519. Lucrezia Borgia, a cura di D. Ghirardo, Tre Lune Edizioni, Mantova 2020) fish, cheese, fruit were exchanged between the court of Este in Ferrara where Lucrezia Borgia had married her third husband, Alfonso I of Este and the court of Mantova where Isabella d'Este, was the wife of Francesco II Gonzaga. The distance between Mantova and Ferrara is around $94 \mathrm{~km}$, much more than that from Ebla and Tuqan. However the messangers of Ebla moved mostly on foot and with donkeys while fast horses were used in 15 cent. AD.!

${ }^{18}$ Pettinato 1992; ARET XI.

${ }^{19}$ For some of the last interpretations s. Biga-Capomacchia 2012; Bonechi 2016; Pasquali 2020 with previous bibliography.

${ }^{20}$ Binaš is the only city of the cultic itinerary identified with certainty with Tell Binniš, 20 kms north-west of Ebla. For Binaš s. ARES II; Bonechi 1993; Ebla Digital Archives, EbDA, Venice. s.v.
} 
NIrar", i.e. the waters coming from NIrar ${ }^{21}$. Masad is a town quoted only a few times in the Ebla texts and quite probably was very close to Ebla, in the territory directly controlled by Ebla $^{22}$. The waters referred to could be the closest waters i.e. with great probability those of the river Qoueiq and of lake Matkh. Like all the villages visited during the ritual, Masad must be in the territory controlled by Ebla. The procession, which visits some holy places of the dinasty of Ebla, goes very slowly with chariots drawn by oxen. Possibly the first stop is a one-day trip from Ebla, around half the way between Ebla and lake Matkh, which is $15 \mathrm{~km}$ from Ebla. Possibly, if we think of a canal from the lake or from the river Qoueiq the distance could also be shorter.

It is therefore possible to suppose that the first stop of the procession to Binaš, after one day's journey $(5-6 \mathrm{~km}$ ?) could be in a place where a canal of water from the river Qoueiq entered the Ebla territory.

It is possible that the lake Matkh and possibly part of the valley of river Qoueiq had been controlled by the kingdom of NIrar.

NIrar was one of the most faithful allies of Ebla and one of the most referred to kingdoms in the Ebla texts.

No wars are ever attested with the kingdom of Nirar. Only good relationships with exchanges of gifts, commerce, visits of the king of NIrar to the Ebla court to swear allegiance etc ${ }^{23}$.

A. Karbotly, in his PhD dissertation, studied the two neighbouring tells, Tell Hader and Tell Qinnasrin. These two sites are in an important position on the river. The distance between them is $3 \mathrm{~km}$. This short distance gave the opportunity to control the river and was like a gate that people had to go through to reach Ebla. Tell Qinnasrin is a small tell but Tell Hader, ca. 16 ha, lying at the east bank of the river Qoueiq was certainly occupied during the EB IVA / EB IVB period. Its strategic position was certainly important and Karbotly proposed identification with NIrar of the archives of Ebla.

In fact, there is no clear textual proof for the identification of NIrar with Tell Tuqan or Tell Hader, but it is probable. A valley important for commerce including timber must have an important city controlling it, as Steinkeller demonstrated recently in an important article in print. He showed that the commerce of timber (especially of fir and cedar wood) was fundamental for Ebla's economy. He proposed locating the kingdom of Armi in Cilicia, controlling the sources of precious timber, especially fir, (Abies cilicica) and reconstructed the long road to bring this wood to Babylonia. On this road, there is the Qoueiq river. He writes ${ }^{24}$ :

"It appears quite likely that, in ancient times, the Matkh, the Kharaitsh, and Sabkhat al-Jabbul contained more water than today. It is even possible that there existed some artificial canals linking some of them. Therefore, even though never forming a single, connected waterway, these bodies of water could, especially during the winter season, effectively be used to transport cargo (either on boats or rafts). Theoretically at least, one may envision that this route began at Tell Tuqan, running then eastward over the Matkh and the Kharaitsh lakes. Having reached their most eastern point, one would then need to transport the cargo overland (by using the Khanaser corridor) to the western bank of Al-Jabbul. There, the cargo would again be loaded on watercraft and transported over Al-Jabbul to the Euphrates.

\footnotetext{
${ }^{21}$ In my opinion, this translation is preferable to "the waters of Masad, that (i.e. Masad) of NIrar", that supposes that Masad is a site of the kingdom of NIrar, depending on the capital city Nirar (quite improbable).

${ }^{22}$ For Masad see ARES II: 378; Bonechi 1993: 229. A study on this town is in preparation by Biga and Karbotly.

${ }^{23}$ See ARES II, s.v.; Bonechi 1993 s.v.; Biga 2008: 306-307; Karbotly 2017: 203-263.

${ }^{24}$ Steinkeller 2020.
} 
The existence of such a waterway would provide Ebla with an obvious advantage over other regional powers.

It may be hypothesised that one relied here on the chain of seasonal saline lakes or lagoons (sabkh), some of which survive in that region even today. Of those, the closest to Ebla is the Matkh lake, which is situated $15 \mathrm{~km}$ east of Ebla. The Matkh is the remnant of an ancient lake extending $30 \mathrm{~km}$ (north-south) and $15 \mathrm{~km}$ (east-west), which had been fed by the perennial waters of the Nahr el-Quweiq, flowing southward from Aleppo. On the western edge of the Matkh, there is situated Tell Tuqan, an important site occupied during the time of Ebla archives. The ancient name of Tell Tuqan is uncertain. Biga (2014: 94 n. 2), suggests an identification with NI-ra-ar ${ }^{\mathrm{ki}}$."

The references to NIrar in the published and still unpublished texts of Ebla are so numerous and the relationships between the two kingdoms so frequent that much study is still necessary ${ }^{25}$. However, from a general view of all the written sources, it can be concluded that NIrar was close to Ebla, and always had very good relationships with it and perhaps also some family ties.

The texts quote a king (probably more than one) and a queen of NIrar, not mentioned with their personal name, several sons of the king of NIrar (quoted by name), and at least 4 daughters of the royal couple of NIrar. The mother of the king of NIrar is quoted too and, on occasion of her death, funerary gifts arrived from Ebla. Then gifts for the purification of her son and his family arrived from Ebla.

An important functionary (ugula) of NIrar at the time of the last king Išar-damu and both his viziers Ibrium and Ibbi-zikir is I-rí-ik-il/ $\mathrm{NI}^{26}$, quoted often receiving textiles. In TM.75.G.1784 (king Išar-damu, vizier Ibrium, month lost) obv. VI 6-12: (3 textiles) I-rí-ik-il ugula NI-ra-arki.

TM.75.G.1763 (king Išar-damu, vizier Ibbi-zikir, month lost) obv. VII 3-8: (3, 3 textiles) 3 dumu-nita dumu-nita/ Si-ti-zé/ NI-ra-ar ${ }^{k i} /$ šeš-šeš/Kéš-du-ut

TM.75.G.1765 (king Išar-damu, vizier Ibbi-zikir, month ha-li-ni) obv. X 5-11: (2 textiles) ì-giš-sag Na-am $\sigma_{6} d a-m u$ NI-ra-ar ${ }^{k i}$ in $A-r u_{12}-g a-d u^{k i}$ šu-ba 4 -ti.

Several merchants (lú-kar) of NIrar are mentioned with their personal name.

For example in TM.75.G.1772 (king Išar-damu, vizier Ibrium, month lost) rev. II 1-6: 1 gu-dùl-TÚG 1 íb+III-gùn-TÚG/ Du-ga-lu/ lú-kar /NI-ra-arki/maškim/I-bi-zi-kir/

Dugalu merchant of NIrar is a functionary of vizier Ibbi-zikir and probably worked with him.

A study of the cities in which envoys of NIrar, messengers, merchants etc. received Eblaite textiles could be useful to verify whether some of these places can be placed in the Qoueiq valley. For example, several times envoys of NIrar receive textiles in the city of Bar$g a-u_{9}{ }^{k i} / B a r-g a^{k i}$, referred to in the Eblaite texts. It could be located in the valley of river Qoueiq. Some scholars have already proposed this, even if the identification of Barga with one of the tells in the river valley is not possible.

It is mentioned among the sites where cultivated lands assignments to a son of vizier Ibrium are recorded ${ }^{27}$.

It is quoted also in several unpublished texts.

\footnotetext{
${ }^{25}$ Several unpublished texts have been already studied by A. Karbotly in his dissertation, s. Karbotly 2017.

${ }^{26}$ His father $\mathrm{Ki}$-li-im was a ugula of NIrar too.

${ }^{27}$ S. ARES II, s.v.; Bonechi 1993: s.v. See also Ebla Digital Archives, Ca Foscari, Venice.
} 


\section{Conclusions}

A more detailed picture of the area around the river Qoueiq is possible now thanks to several surveys and studies, but the problem to identify the surveyed sites with ancient toponyms remains.

Apart from the big city of Aleppo, which is close to the river Qoueiq and well known, all the many tells along the river Qoueiq are known only from surveys.

Along the river Qoueiq there are many tells, some of them certainly dated to the third millennium BC, whose name must be present in the Ebla texts. So far, it has not been possible to identify any of these tells with toponyms quoted in the Ebla texts.

The river Qoueiq was the road followed to go from Aleppo to Ebla. As Del Fabbro reconstructed, "considering the geo-morphological features of the territory and the disposition of settlements, it is presumable that, moving from Aleppo, during the first day the river Quwayq was followed. An itinerary at first westward, as far as Khan al'Asl, then southward along the course of Wadi al-Kabir that flows into the river Quwayq itself, cannot be excluded. If this reasoning is correct, it is likely that the intermediate stop between Aleppo and Ebla was Al-Hadr (Tell Hader), a site of ca 20 hectares, located $25 \mathrm{~km}$ south-southeast of Aleppo and occupied in the Early Bronze IV A-B, Middle Bronze and Late Bronze Age. After Al-Hadr, the path is quite free and the last $30 \mathrm{~km}$ could be covered in an almost straight line" 28 .

From the cuneiform texts of the Ebla archives many names of farms and villages in the Eblaite territory are quoted and some of them are already published ${ }^{29}$.

Many other names of villages and farms around Ebla are quoted in the trapezoidal archive L. 2764 and not yet studied.

It will always be impossible to identify these farms and villages with tells because most of them did not produce or leave a tell. If we take a map of an Italian province in the Roman period or in any period of the history, we can verify how many farms and villages there were around even every small centre.

Archaeological data on the region of Matkh and the valley of the river are from surveys while most of the tells have yet to be excavated. No cuneifom tablets or inscriptions useful for identification have been found in any of the few excavated sites.

What we know from archaeology and from the Ebla texts is not enough to allow any certain identification of an ancient name with a modern tell even for the excavated tells in the river Qoueiq valley such as Tell Tuqan, or the not too distant Tell Mastuma, or Tell Afis, in a region nearby.

In any case an identification of the ancient capital city of NIrar with Tell Tuqan (more probably) or Tell Hader or in any case along the valley of river Qoueiq is likely.

\section{Abbreviations}

ARET Archivi Reali di Ebla. Testi

ARET V= Edzard, D.O., 1984, Hymnen, Beschwörungen und verwandtes (aus dem Archiv L. 2769), Roma.

ARET XI=Fronzaroli, P., 1993, Testi rituali della regalità, (Archivio L.2769), Roma.

ARET XVI= Catagnoti, A.- Fronzaroli, P., 2010, Testi di cancelleria: il re e i funzionari, I, (Archivio L. 2769), Roma.

\footnotetext{
${ }^{28}$ Del Fabbro: 216.

${ }^{29}$ Archi 1992; Milano 1996: 158-168 where some names of villages located around Ebla in which agricultural activities were performed are listed.
} 
ARES Archivi Reali di Ebla. Studi

ARES II= Archi, A et al., 1993, I nomi di luogo dei testi di Ebla, Roma.

EbDA Ebla Digital Archives (http://ebda.cnr.it)

TM Tell Mardikh

s.v. sub voce

s. see

\section{Bibliography}

Archi, A., 1992, "The City of Ebla and the Organization of the Rural territory", AoF 19, pp. 24-28.

Baffi, F. (ed.), 2011, Tell Tuqan. Excavations 2008-2010, Galatina, Lecce.

Baffi, F.-Peyronel, L., 2013, "Trends in Village Life. The Early Bronze Age Phasrs at Tell Tuqan, in P. Matthiae and N. Marchetti (eds.), Ebla and its Landscape. Early State Formation in the Ancient Near East, Walnut Creek, CA, pp. 195-214.

Biga, M.G., 2008, “Au-delà des frontières: guerre et diplomatie à Ebla”, Orientalia 77, pp. 289-334.

Biga, M.G., 2013, "Defining the Chora of Ebla. A Textual Perspective", in P. Matthiae and N. Marchetti (eds.), Ebla and its Landscape. Early State Formation in the Ancient Near East, Walnut Creek, CA, pp. 259-267.

Biga, M.G., 2014, "Inherited Space - Third Millennium Political and Cultural Landscape" in E. Cancik-Kirschbaum, N. Brisch, J. Eidem (eds.), Constituent, Confederate, and Conquered Space. The Emergence of the Mittani State, TOPOI Berlin Studies of the Ancient World 17, Berlin, 2014, pp. 93-110.

Biga, M.G., 2016, “La Syrie et l'Egypte au III millénaire av. J.-C. d'après les archives d'Ebla, Comptes rendus de l'Académie des Inscriptions et Belles Lettres 2016, pp. 691-711.

Biga, M.G.-Capomacchia, A.M.G., 2012, "I testi di Ebla di ARET XI: una rilettura alla luce dei testi paralleli”, $R A$ 106, pp. 19-32.

Biga, M.G.- Roccati, A., 2012, “Tra Egitto e Siria nel III millennio a.C.”, in Atti dell'Accademia delle Scienze di Torino 146, pp. 17-36.

Biga, M.G., Steinkeller, P., "In Search of Dugurasu”, JCS, in print.

Bonechi, M., 1993, I nomi geografici dei testi di Ebla, RGTC 12/1, Wiesbaden.

Bonechi, M., 1999, “Lexique Hydrographique à Ebla”, in L. Milano et al. (eds.), Landscapes, territories, Frontiers and Horizons in the Ancient Near East, Papers presented to the XLIV Rencontre Assyriologique Internationale, Venezia, 7-11 July 1997, Padova, pp. 97-101.

Bonechi, M., 2016, “A Passive, and Therefore Prized, Bride. New Proposals for the Queen's Wedding in the Ebla Royal Rituals", RA 110, pp. 53-78.

Del Fabbro, R., 2012, "The Roads from and to Aleppo: Some Historical-geographical Considerations in Light of New Archaeological Data" in G.B. Lanfranchi et al. (eds.), Leggo! Studies Presented to Frederick Mario Fales on the Occasion of His $65^{\text {th }}$ Birthday, Harrassowitz VerlagWiesbaden, pp. 201-222. 
Karbotly, A., 1917, Relazioni della città di Ebla con regni vicini e con altre città siriane nel XXIV sec. a.C., unpublished PhD dissertation, Rome, Sapienza Università di Roma.

Knitter, D. et al., 2014, "The Centrality of Aleppo and its Environs", in eTopoi, Journal for Ancient Studies 3, pp. 107-127.

Liverani, M., 1965, "I tell pre-classici" in Missione archeologica italiana in Siria: Rapporto preliminare sulla campagna 1964 (Tel Mardikh), Roma: Centro di studi semitici, Istituto di studi del Vicino Oriente, pp. 107-133.

Maigret, A. de, 1978, "Fluttuazioni territoriali e caratteristiche tipologiche degli insediamenti nella regione del Matah (Siria). Nota preliminare", in Atti del 1 Convegno Italiano sul Vicino Oriente antico (Roma, 22-24 aprile 1976) (Orientis Antiqui Collectio XIII), Roma, pp. 83-94.

Mantellini, S., 2013, “ Regional Approach and Archaeological Surveys in Northern Syria. An Overview", in P. Matthiae and N. Marchetti (eds.), Ebla and its Landscape. Early State Formation in the Ancient Near East, Walnut Creek, CA, pp. 238-256.

Matthers, J., (ed.), 1981, The River Qoueiq, Northern Syria and its Catchment: Studies Arising from the Tell Rifa'at Survey 1977-1979, Oxford.

Matthiae, P., 2014, "A Note on Tell Tuqan and the Archaic Urbanization in Western Syria", in F. Baffi-R.Fiorentino-L.Peyronel (eds.), Tell Tuqan Excavations and Regional Perspectives Cultural Developments in Inner Syria from the Early Bronze Age to the Persian/Hellenistic Period, Proceedings of the International Conference May 15 $5^{\text {th }}-17^{\text {th }}$ 2013, Galatina, Lecce, pp. 35-44.

Milano, L., 1996, "Ebla: gestion de terres et gestion des ressources alimentaires", in J.-M. Durand (ed.), Mari, Ebla et les Hourrites: dix ans de travaux. Première partie. Actes du Colloque international (Paris, Mai 1993), Amurru I, Paris, pp. 135-171.

Pasquali, J., 2020, “Le rôle du soleil et de l'eau dans le culte des ancêtres d'après les données épigraphiques éblaites à la lumière de la religion comparée et de l'ethnologie", in I. Arkhipov et al. (eds.), The Third Millennium, Leiden-Boston, pp. 595-616.

Pettinato, G., 1992, Il rituale per la successione al trono a Ebla, Roma.

Steinkeller, P., 2020, "International Trade in Greater Mesopotamia during Late Pre-Sargonic Times: The Case of Ebla as Illustrated by Her Participation in the Euphratean Timber Trade", in Actes of a Gottingen conference, in print.

Vacca, A., 2019, "Some Reflections about the Chora of Ebla during the EBIII and IVA 1 Periods", in M. D'Andrea et al, Pearls of the Past, Zaphon Muenster, pp. 869-898. 


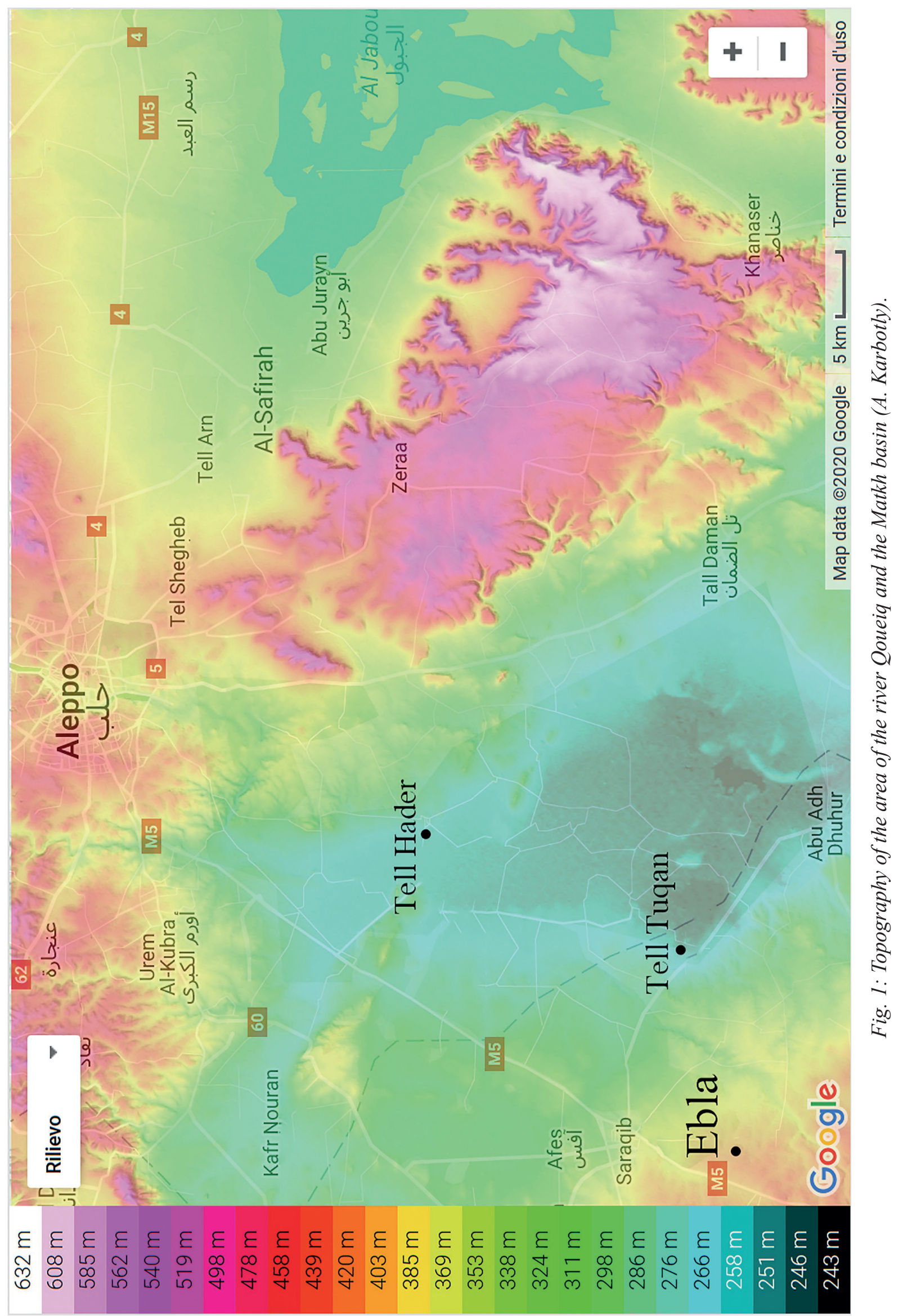




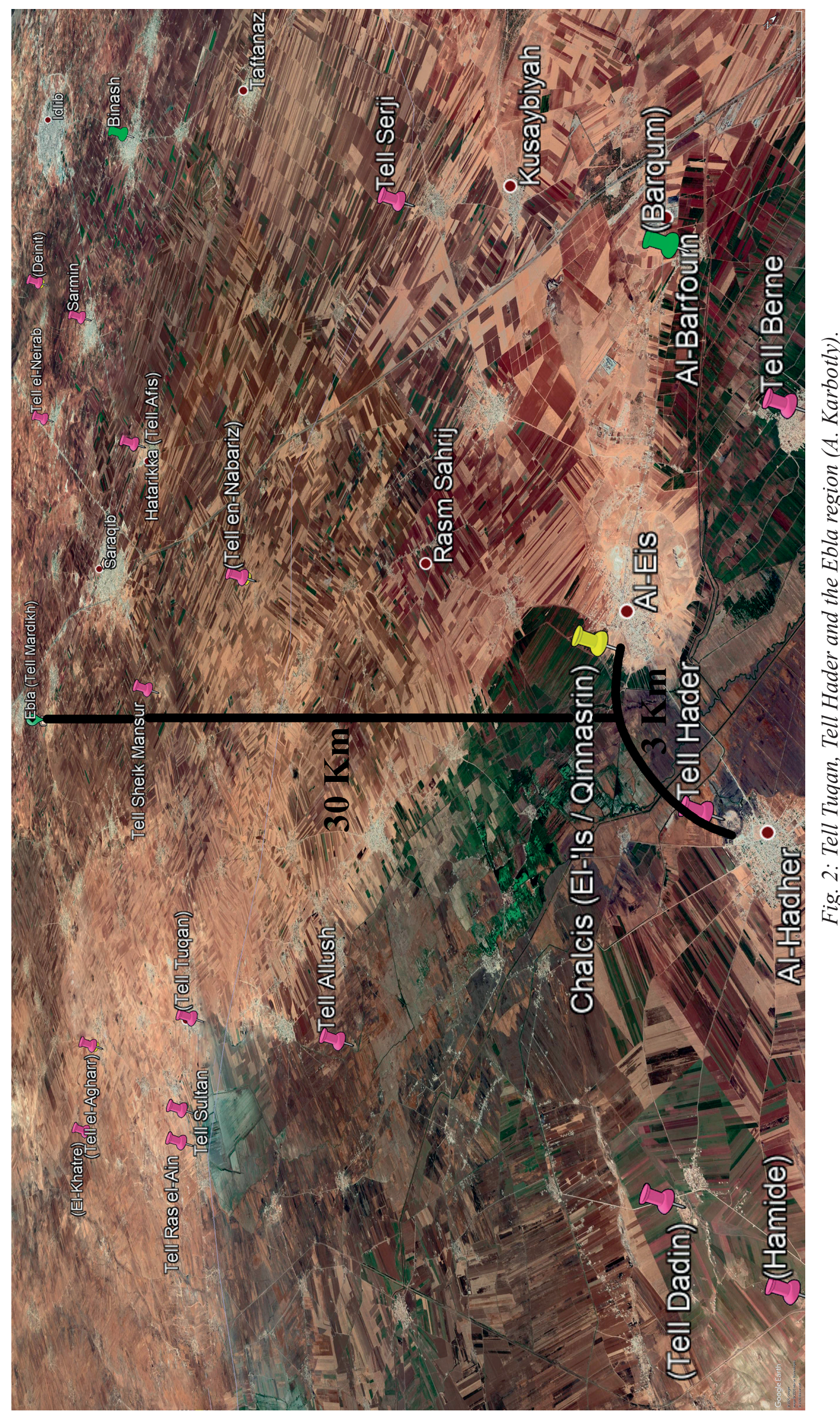




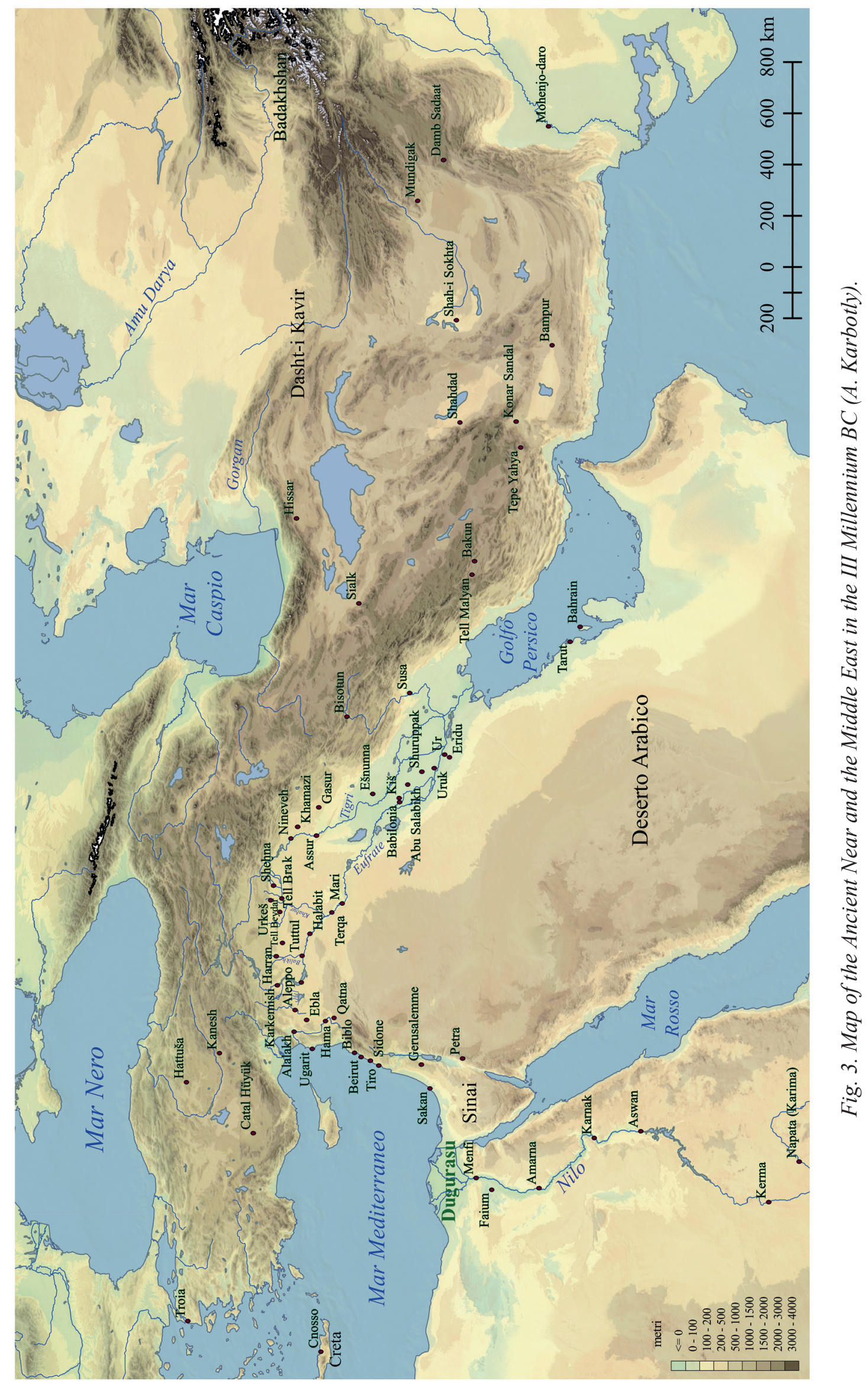

